\title{
Transient Anti-GAD Antibody Positivity and Acute Pancreatitis with Pancreas Tail Swelling in a Patient with Susceptible Haplotype for Type 1 Diabetes Mellitus
}

\author{
Toshio Kahara ${ }^{1}$, Toshinari Takamura ${ }^{2}$, Toshiki Otoda ${ }^{1}$, \\ Kazuhide Ishikura ${ }^{1}$ and Eiki Matsushita ${ }^{1}$
}

\begin{abstract}
A 57-year-old man was admitted to our hospital complaining of poor appetite. He had been diagnosed with diabetes mellitus and was anti-GAD antibody (GAD-Ab) negative 1 year previously, at the age of 56 years old. Abdominal CT revealed pancreas tail swelling; elastase-I level was elevated and he was diagnosed with pancreatitis. The level of GAD-Ab was increased and HLA haplotype was DRB $1 * 0901-\mathrm{DQB} 1 * 0303$, which is seen frequently in type 1 diabetic Japanese patients. However, his endogenous insulin secretion ability was not deteriorated. After elastase-I level and pancreas swelling improved, GAD-Ab returned to a normal range. One year after the onset of pancreas swelling, he was still not in an insulin-dependent state. In this case, transient GAD-Ab positivity with susceptible haplotype for type 1 diabetes mellitus might have been induced by a GAD antigen discharged from the destroyed islet due to pancreatitis.
\end{abstract}

Key words: anti-GAD antibody, pancreatitis, type 1 diabetes mellitus, HLA

(Inter Med 48: 1897-1899, 2009)

(DOI: 10.2169/internalmedicine.48.2393)

\section{Introduction}

Acute pancreatitis can be accompanied by glucose metabolism abnormality, but it is normalized after pancreatitis treatment. In general, beta-cells are not destroyed during the inflammation of the exocrine tissue such as in typical pancreatitis because the islets of Langerhans in human are somewhat encapsulated. On the other hand, there are some reports of insulin-dependent diabetes mellitus negative for anti-glutamic acid decarboxylase antibody (GAD-Ab) after acute pancreatitis, and some of these cases are regarded as fulminant type 1 diabetes mellitus (1-4). GAD-Ab is frequently seen in type 1 diabetes, and the destruction of islet beta cells can lead to discharge of GAD (5); however, $\mathrm{GAD}-\mathrm{Ab}$ is not detected in chronic pancreatitis patients with diabetes mellitus-related HLA haplotype (6). We encountered a case of acute pancreatitis with a susceptible haplo- type for type 1 diabetes mellitus that had transient GAD-Ab positivity but endogenous insulin secretion ability did not deteriorate.

\section{Case Report}

A 56-year-old man was admitted to our hospital because of congestive heart failure by dilated cardiomyopathy; he was noted to have diabetes mellitus. There was no familial history of diabetes mellitus. GAD-Ab was negative and urinary excretion of C peptide (u-CPR) was within normal limits $(105.3 \mu \mathrm{g} / \mathrm{day})$. Abdominal ultrasonography revealed no abnormalities in the pancreas. He had had diabetic neuropathy, but no diabetic retinopathy. His blood glucose level was improved by a meal of 1,680 kcal/day during hospitalization and he was discharged with only a dietary intervention for his diabetes mellitus. In February 2008, he was admitted to our hospital complaining of poor appetite without abdominal

${ }^{1}$ Department of Internal Medicine, Kahoku Central Hospital, Ishikawa and ${ }^{2}$ Department of Disease Control and Homeostasis, Kanazawa University Graduate School of Medical Science, Kanazawa

Received for publication April 22, 2009; Accepted for publication July 30, 2009

Correspondence to Dr. Toshio Kahara, kchizu1230@yahoo.co.jp 
Table 1. Laboratory Findings and Clinical Course

\begin{tabular}{|c|c|c|c|c|c|c|c|c|}
\hline & & reference range & Sep,2007 & Feb,2008 & Mar,2008 & Apr,2008 & May,2008 & Jun,2008 \\
\hline WBC & $(/ \mu \mathrm{L})$ & $3,900-9,800$ & 11,900 & 11,400 & 9,200 & 8,100 & 8,100 & 8,000 \\
\hline CRP & $(\mathrm{mg} / \mathrm{dL})$ & $<0.30$ & 0.39 & 1.33 & 0.21 & 0.12 & & 0.08 \\
\hline AST & $(\mathrm{U} / \mathrm{L})$ & $13-33$ & 46 & 99 & 36 & 35 & 30 & 35 \\
\hline ALT & (U/L) & $8-42$ & 38 & 92 & 41 & 38 & 30 & 34 \\
\hline ALP & (U/L) & $115-359$ & 449 & 551 & 536 & 402 & 456 & 361 \\
\hline$\gamma$-GTP & $(\mathrm{U} / \mathrm{L})$ & $10-47$ & 747 & 423 & 327 & 253 & 180 & 203 \\
\hline AMY & $(U / L)$ & $40-130$ & 62 & 126 & 82 & 79 & 91 & 83 \\
\hline Elastase-1 & (mg/dL) & $72-432$ & & 1487 & 436 & & & 224 \\
\hline $\mathrm{HbA1c}$ & $(\%)$ & $4.3-5.8$ & 7.0 & 7.9 & 8.4 & 8.6 & 7.4 & 6.9 \\
\hline FPG & $(\mathrm{mg} / \mathrm{dL})$ & $69-109$ & & 186 & & 132 & & \\
\hline$s-C P R$ & (ng/mL) & $0.8-2.5$ & & 3.5 & & 2.9 & & \\
\hline u-CPR & ( $\mu \mathrm{g} /$ day) & $22.8-155.2$ & 105.3 & 119.9 & & & & \\
\hline $\mathrm{GAD}-\mathrm{Ab}$ & $(\mathrm{U} / \mathrm{mL})$ & $<1.4$ & $<1.3$ & 2.3 & $<1.3$ & & & \\
\hline $\mathrm{IA}-2 \mathrm{Ab}$ & $(\mathrm{U} / \mathrm{mL})$ & $<1.0$ & & $<0.4$ & & & & \\
\hline BNP & $(\mathrm{pg} / \mathrm{mL})$ & $<18.4$ & 274.3 & 28.4 & & & & \\
\hline \multicolumn{4}{|c|}{ Medical treatment } & $\begin{array}{l}\text { valsartan } 40 \\
\text { voglibose } 0.6\end{array}$ & & \multicolumn{3}{|c|}{$\begin{array}{l}\text { valsartan } 40 \mathrm{mg} \\
\text { voglibose } 0.6 \mathrm{mg} \\
\text { buformine hydrochloride } 100 \mathrm{mg}\end{array}$} \\
\hline
\end{tabular}
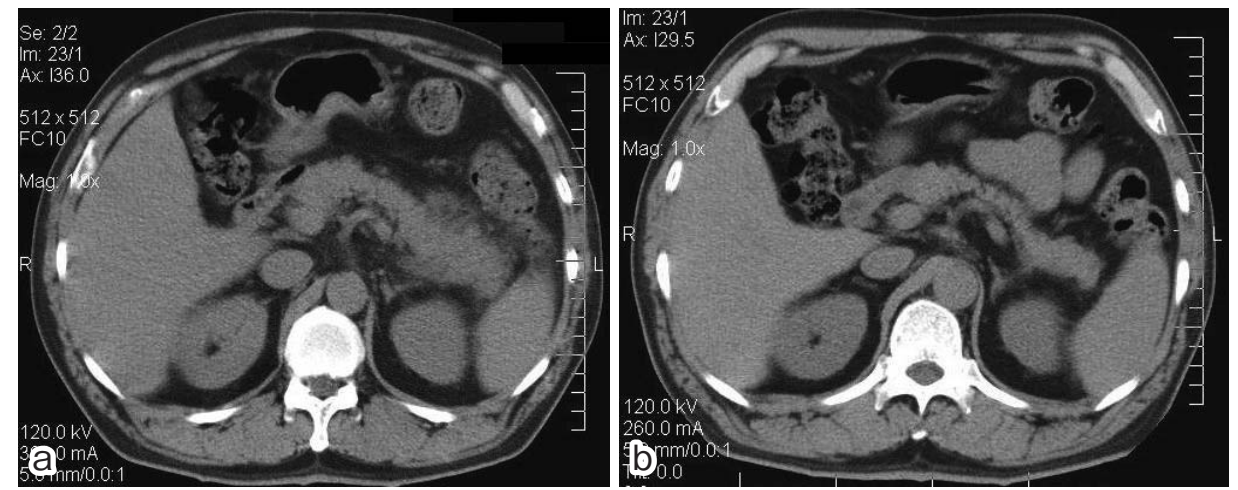

Figure 1. Abdominal CT revealed pancreas tail swelling in February 2008 (a). The pancreatic swelling improved after two months (b).

pain at the age of 57 years old. He had been drinking approximately $240 \mathrm{kcal} /$ day of "sake" (shochu), a Japanese alcoholic beverage made from rice. On physical examination, his body mass index was $26.0 \mathrm{~kg} / \mathrm{m}^{2}$, his body temperature was $36.7^{\circ} \mathrm{C}$ and there was mild epigastric tenderness. Laboratory tests revealed liver dysfunction and hyperglycemia, as shown by the following findings: white blood cell counts (WBC) $11,400 / \mu \mathrm{L}, \mathrm{C}$-reactive protein (CRP) $1.33 \mathrm{mg} / \mathrm{dL}$, aspartate aminotransferase (AST) $99 \mathrm{U} / \mathrm{L}$, alanine aminotransferase (ALT) $92 \mathrm{U} / \mathrm{L}, \boldsymbol{\gamma}$-glutamyltranspeptidase $(\gamma$ GTP) $423 \mathrm{U} / \mathrm{L}$, alkaline phosphatase (ALP) $551 \mathrm{U} / \mathrm{L}$, amylase (Amy) $126 \mathrm{U} / \mathrm{L}$, elastase-I $1,487 \mathrm{mg} / \mathrm{dL}$, hemoglobin A1c (HbA1c) 7.9\%, fasting plasma glucose (FPG) $186 \mathrm{mg} /$ $\mathrm{dL}$, serum C-peptide (s-CPR) $3.5 \mathrm{ng} / \mathrm{mL}$, GAD-Ab $2.3 \mathrm{U} /$ mL, IA-2 antibody (IA-2 Ab) $<0.4 \mathrm{U} / \mathrm{mL}$ (Table 1). Thyroid hormone levels were within normal limits and thyroidrelated autoantibodies were negative. Hepatitis B surface antigen (HBsAg), hepatitis C virus antibody (HCVAb), antinuclear antibody (ANA), anti-mitochondrial antibody (AMA) were all negative. Abdominal computed tomography (CT) revealed pancreas tail swelling (Fig. 1a). Contrastenhanced CT revealed no mass in the pancreas, and magnetic resonance cholangiopancreatography (MRCP) revealed no abnormalities in the pancreatic duct. There was no evi- dence of acute pancreatitis due to viral infections such as Coxsackie virus, Epstein Barr virus, cytomegalovirus or herpes simplex virus. IgG4 level was within normal limits (53 $\mathrm{mg} / \mathrm{dL}$ ). The tentative diagnosis was alcohol-induced acute pancreatitis, and the pancreatic swelling improved with alcohol abstinence and without antibiotics agents after two months (Fig. 1b). HLA haplotype was DRB1*0901-DQB1* 0303 (homozygotes), which is seen frequently in patients with insulin-dependent diabetes mellitus who are GAD-Ab positive (7). However, his endogenous insulin secretion ability did not deteriorate (u-CPR $119.9 \mu \mathrm{g} / \mathrm{day}$ ), both arginine $300 \mathrm{mg}$ loading test and glucagon $1 \mathrm{mg}$ loading test also showed a good reaction of s-CPR (arginine $300 \mathrm{mg}$ loading test: s-CPR $3.1 \mathrm{ng} / \mathrm{mL}$ to $7.1 \mathrm{ng} / \mathrm{mL}$, glucogon $104 \mathrm{pg} / \mathrm{mL}$ to $455 \mathrm{pg} / \mathrm{mL}$, glucagon $1 \mathrm{mg}$ loading test: s-CPR $3.0 \mathrm{ng} /$ $\mathrm{mL}$ to $5.0 \mathrm{ng} / \mathrm{mL}$ ). He had been treated with valsartan 40 $\mathrm{mg}$ and voglibose $0.6 \mathrm{mg}$. GAD-Ab became negative after discharge. As is shown Table 1, the improvement of blood glucose level turned worse after discharge, but had improved without insulin induction after May 2008. One year passed from the onset of pancreas swelling, but he did not go into an insulin-dependent state (FPG $164 \mathrm{mg} / \mathrm{dL}$ and s-CPR 3.7 $\mathrm{ng} / \mathrm{mL}$ in February 2009). 


\section{Discussion}

It is reported that GAD-alum may contribute to the preservation of residual insulin secretion in patients with recentonset type 1 diabetes (8). These results support the hypothesis that GAD is one of the strongest candidate autoantigens involved in triggering beta-cell-specific autoimmunity. On the other hand, GAD-Ab can be detected in the serum of infants of GAD-Ab positive mothers though the infants do not develop diabetes mellitus, including those infants born to mothers who develop overt type 1 diabetes mellitus during pregnancy (9). In addition, type 1 diabetes mellitus has been reported in a patient with agammaglobulinemia, where B cells are severely depleted (10). Hence, there is some controversy regarding the roles of GAD and GAD-Ab in the pathogenesis of type 1 diabetes mellitus.

There was a case report of fulminating-onset type 1 diabetes mellitus following acute pancreatitis (4). This case was positive for GAD-Ab $(4.3 \mathrm{U} / \mathrm{mL})$, although HLA type in the DR region was DR2. According to the clinical course, it was thought that the exposure of beta cell-derived autoantigen induced by pancreatitis caused autoimmunity for beta cells, and lead to the destruction of beta cells, followed by the onset of type 1 diabetes mellitus. However, Lampeter EF et al reported that GAD-Ab was not detected in patients with islet cell damage associated with pancreatitis who had diabetes-associated HLA haplotypes (6).

The present case might be different from a typical case of pancreatitis because he did not have abdominal pain and the acute pancreatitis spontaneously remitted without antibiotic drug. There was no episode of viral infection-like symptom before the onset of pancreatitis. Also there was not finding of autoimmune pancreatitis. In this case, GAD-Ab became positive at the time of pancreas tail swelling. Transient GAD-Ab positivity might have been merely induced immunologically by a GAD antigen discharged from the destroyed islet. However, insulin secretion ability was not deteriorated, although the HLA haplotype in the present case was DRB1*0901-DQB1*0303 which is frequently seen in Japanese patients with insulin-dependent diabetes mellitus who are anti-GAD antibody positive (7).

It is widely accepted that autoimmune islet cell destruction is a $\mathrm{T}$ cell-dependent process. Despite the importance and utility of GAD-Ab for disease prediction, it is controversial whether GAD-Ab by itself causes beta-cell destruction. Accumulation of these cases is important when considering the significance of GAD-Ab with pancreatitis.

\section{References}

1. Moriai T, Morita Y, Matsui T, Okada M. Type 1 diabetes mellitus associated with clinical acute pancreatitis in an adult. Pancreas 20: 415-416, 2000.

2. Nagaoka T, Terada M, Miyakoshi H. Insulin-dependent diabetes mellitus following acute pancreatitis caused by herpes simplex virus; a case report. J Japan Diab Soc 44: 335-340, 2001

3. Sakurai M, Nishimura Y. A case of diabetes mellitus associated with acute pancreatitis. J Japan Diab Soc 45: 415-420, 2002.

4. Inoue $\mathrm{G}$, Sakurai T, Tanaka K, et al. Simultaneous onset of type 1 diabetes mellitus and painless thyroiditis following acute pancreatitis. Intern Med 40: 515-518, 2001.

5. Smismans A, Ling Z, Pipeleers D. Damaged rat beta cells discharge glutamate decarboxylase in the extracellular medium. Biochem Biophys Res Commun 228: 293-297, 1996.

6. Lampeter EF, Seifert I, Lohmann D, et al. Inflammatory islet dam- age in patients bearing HLA-DR3 and/or DR4 haplotypes does not lead to islet autoimmunity. Diabetologia 37: 471-475, 1994.

7. Takeda H, Kawasaki E, Shimizu I, et al. Clinical, autoimmune, and genetic characteristics of adult-onset diabetic patients with GAD autoantibodies in Japan (Ehime study). Diabetes Care 25: 995-1001, 2002.

8. Ludvigsson J, Faresjö M, Hjorth M, et al. GAD treatment and insulin secretion in recent-onset type 1 diabetes. N Engl J Med 359: 1909-1920, 2008.

9. Koczwara K, Bonifacio E, Ziegler AG. Transmission of maternal islet antibodies and risk of autoimmune diabetes in offspring of mothers with type 1 diabetes. Diabetes 53: 1-4, 2004.

10. Martin S, Wolf-Eichbaum D, Duinkerken G, et al. Development of type 1 diabetes despite severe hereditary B-cell deficiency. N Engl J Med 345: 1036-1040, 2001.

(C) 2009 The Japanese Society of Internal Medicine http://www.naika.or.jp/imindex.html 